\title{
Intersectionality done right
}

\section{Disability, war, race, work, capitalism, gender and embodiment}

Jasbir K. Puar:

The Right to Maim - Debility, Capacity, Disability

Duke University Press, 2017. 296 pages. Price: 26,95 USD.

Sometimes a book stays with you long after you turned over its last page. Most scholars probably have a handful of favourite books that they keep returning to. I know I do. Books I keep close by or prefer to take with me because they always somehow 'turn out useful' no matter what I'm working on. This can be the case for many reasons - some of my favourite books unfold difficult theory much clearer than I myself can ever manage to do and others simply inspire me with their language, perspectives and idealisms. For this reason, books like Extraordinary Bodies (1997) by Rosemarie Garland-Thomson, Exile and Pride (1999) by Eli Clare and Feminist, Queer, Crip (2013) by Alison Kafer are hardly readable anymore due to all my notes on their pages - or even recognisable as books anymore. The Right to Maim by Jasbir Puar has quickly added itself to this list of favourites that, over and over again, call on me to re-read, think about, and engage with their ideas and critiques.
Enough of the small talk, what's it about?

According to Puar herself The Right to Maim is "(...) first and foremost about biopolitics" (p. xxv). Building on the theoretical framework of assemblage theory by Deleuze and Guattari, Puar considers the mechanism by which debility, disability and capacity are employed under neoliberalism in order to produce and maintain precarious populations. Within this framework, disability becomes an assemblage of sensations, affects, and forces rather than an identity. Drawing also on the work of Lauren Berlant, Puar pays special attention to the interdependent relationship between bodily capacity and bodily debility in her search for an answer to the question: Which bodies are made to pay for 'progress'? (p. 13). Using examples that span from gay youth suicide and the "It Gets Better" campaign to Israeli occupation and oppression strategies, Puar argues that neoliberalism's 
heightened demands for bodily capacity simultaneously produce and mark out populations for “(...) 'slow death' - the debilitating ongoingness of structural inequality and suffering" (p. 1). Rather than opposites, capacity and debility are in fact "generated by increasingly demanding neoliberal formulations of health, agency, and choice - what I call liberal eugenics of lifestyle programming that produce, along with biotechnologies and bioinformatics, population aggregates" (p. 13). According to Puar, it is this ongoing and (seemingly) never-ending biopolitical population control and evaluation of all bodies "(...) in relation to their success or failure in terms of health, wealth, progressive productivity, upward mobility, [and] enhanced capacity" (p. 15) that propagate the construction of both failed and capacitated bodies. A large portion of the book focuses on the Israel/ Palestine conflict, and in particular the mass-scale injuries inflicted on Palestinian bodies by the Israeli state in the name of defence. In contrast to a state's "right to kill", the "right to maim", which is often thought of as the more 'humane' alternative, implies the liberty to injure bodies in the name of defence. Such maiming, according to Puar, leaves the Palestinian people in a debilitating state (in several ways) of 'slow death'. Maiming, then, is about producing precarious populations and keeping them scarcely alive because it is more profitable than exterminating them all together.

\section{Puar's objections - and mine}

Like in Terrorist Assemblages (2007), Puar's thinking is anything but conventional and she further develops her thoughts on and use of assemblage theory. Perhaps for this reason, Puar also in The Right to Maim dismisses disability as an individual identity as well as the otherwise popular social model of disability. Used by many disability scholars in their theorisation of disability the model distinguish between impairment (e.g. bodily differences and/or intellectual, physical, sensory, or psychological variations in people) and disability (systemic and excluding structural barriers in society that contribute to the disabling of people).
For Puar however, such categories are too rigid in explaining the complex mechanism that produce capacity, debility and disability. Instead Puar puts forward a new biopolitical concept, the right to maim, in order to unfold the mechanisms producing both capacitated and failed bodies. Thus, according to Puar, the disability activist movement, while admirable for its hard work and accomplishments in securing help for people with disabilities, needs to broaden its scope and realise that capitalism is what is both producing and sustaining the 'need' for precarious population. Thus, within a capitalist logic mutilation and amputation following accidents "are part of the biopolitical scripting of populations available for injury, whether through labor or warring or both" (p. 64). What I find particularly remarkable about The Right to Maim is the global perspective on disability that Puar applies. Very convincingly (and effortlessly it seems, hence the title of this review) she uncovers and discusses the many and complex interrelations between race, embodiment, gender, war and work (to mention just a few), and in doing so she emphasises that individual, local or even national explanations of (not to mention solutions to) the inequalities structuring (dis)ability are inadequate and need to be broadened.

As disability scholar Lennard Davis in his review ${ }^{1}$ of The Right to Maim has already pointed out though, Puar's impressive web of thought-provoking insights and complex critiques can - however impressive they may be - prove somewhat difficult for many in the disability community to 'put into use' in their everyday practices. I agree with Davis that while the work of Puar (and especially her global perspective on disability) is highly important, it is equally important to remember that disability, pain and suffering is an ongoing, never-ending and 'everyday' experience for many who want and need to see change here and now. One might therefore (and rightfully so, I think) be somewhat sceptical of the 'usefulness' of an exceedingly academic, theoretical and philosophical analysis of and approach to disability.

So, who will find this book useful? While not everyone will necessarily agree with Puar on all her conclusions, anyone interested in disability studies 
should read this book. Anyone working with intersectionality or assemblage theory should do the same. And anyone who wants to introduce Puar's thoughts and critiques to their students should do so, but make sure to provide a helping hand in dissecting and digesting it. In conclusion then, The
Right to Maim is on the one hand and without a doubt a highly(!) intellectual and not at all an easy read, but it does, on the other hand, offer new and extremely important insights into critical disability studies - an academic field many (if not most) of us need to know much, much more about it.

CAMILLA BRUUN ERIKSEN, Assistant Professor at the Department for the Study of Culture, University of Southern Denmark.

\section{Note}

1 https://criticalinquiry.uchicago.edu/lennard_davis_reviews_the_right_to_maim/ (accessed July 22nd 2019)

\section{Literature}

Clare, E. 1999. Exile and Pride. Disability, Queerness \& Liberation. Boston: South End Press.

Garland-Thomson, R. 1997. Extraordinary Bodies. Figuring Physical Disability in American Culture and Literature. New York: Columbia University Press.

Kafer, A. 2013. Feminist, Queer, Crip. Bloomington \& Indianapolis: Indiana University Press.

Puar, J. 2007. Terrorist Assemblages. Homonationalism in queer times. Durham \& London: Duke University Press. 